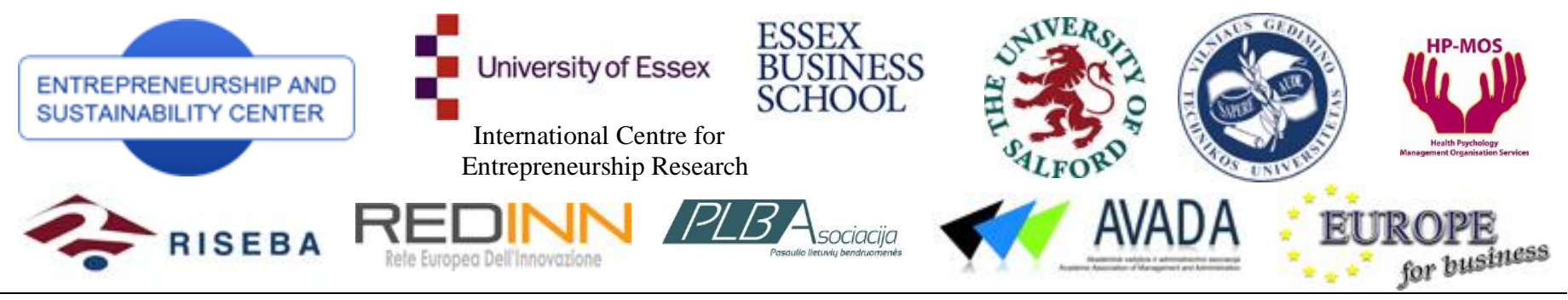

ENTREPRENEURSHIP AND SUSTAINABILITY ISSUES

ISSN 2345-0282 (online) http://jssidoi.org/jesi/

\title{
METHODOLOGY OF COMPLEX ANALYSIS OF COMPANIES' PROFITABILITY
}

\author{
Daiva Tamulevičienè \\ Vilnius University, Faculty of Economics, department of Accounting and Audit, Sauletekio 9, LT-10222, Lithuania \\ E-mail: daiva.tamuleviciene@ef.vu.lt
}

Received 10 March 2016; accepted 18 June 2016

\begin{abstract}
Profitability is one of the most important companies' activity indicators. In the article, all profitability ratios are divided into three groups: sales, assets and equity. The importance of their analysis is underlined. In the financial analysis literature, the most common calculations of various financial indicators provided lack attention of their analysis. The complex analysis methodology recommended in the article comprises: 1) determination of analysis aims; 2) choice of analysis sources and technical methods; 3) calculation and evaluation profitability of sales (gross and net), profitability of assets (total assets, fixed and current assets), profitability of equity (authorized capital, shareholders' equity and capital employed); 4) determination of factors influencing profitability; 5) usage of information collected during the analysis for internal and external users purposes. The recommended complex analysis methodology can be successfully applied to companies of various size and activity. After successfully applying it, it is possible to objectively evaluate efficiency of company's activity, potential risks, competitiveness and possibilities of continuity.
\end{abstract}

Keywords: net profit, gross profit, complex analysis, profitability of sales, profitability of assets, profitability of equity, profitability ratios.

Reference to this paper should be made as follows: Tamulevičienè, D. 2016 Methodology of complex analysis of companies' profitability, Entrepreneurship and Sustainbility Issues 4 (1): 53-63.

DOI: http://dx.doi.org/10.9770/jesi.2016.4.1(5)

JEL Classifications: M49

\section{Introduction}

In order to objectively evaluate efficiency of company's activity, its competitiveness and possibilities of continuity, it is crucial to calculate and evaluate the profitability ratios. Especially, a lot of useful information is obtained when comparing the profitability ratios of the financial year with the profitability ratios of the previous financial years, other similar companies and average rates of industry sectors' profitability.

However, a question arises how and which profitability ratios should be calculated, named and evaluated? Various Lithuanian and foreign authors provide different names for profitability ratios and a different number of 


\section{The International Journal \\ ENTREPRENEURSHIP AND SUSTAINABILITY ISSUES}

ISSN 2345-0282 (online) http://jssidoi.org/jesi/

2016 Volume 4 Number 1 (September)

them in their scientific articles. The scientists of economic theory usually suggest to calculate two profitability ratios: gross profit margin and net profit margin. It is appropriate to name these ratios as gross and net profitability of sales because they are calculated by respectively dividing gross and net profit from sales revenue. However, these two indicators are not enough to fully evaluate efficiency of company's activity. Since the company's profit is to a large extent dependent on efficient usage of assets and equity, it is obligatory to calculate and analyse not only profitability of sales but also profitability of assets and equity ratios. In many works of foreign authors (Gibson, 1992, 2012; Stickney, 1993; Fridson and Alvarez, 2011; Maynard, 2013; Plenborg and Petersen, 2011; Stickney, Brown and Wahlen, 2006 and others), two terms are used to describe profitability: "profitability" and "return". The term "profitability" is used when analysing sales profitability ratios, whereas "return" describes assets and equity profitability. It is necessary to agree with J. Mackevičius opinion that it is not accurate. If profit is divided from sales revenue when calculating profitability, then it is named as sales profitability. Therefore, if we divide profit from assets or equity, these ratios have to be called assets and equity profitability instead of "return" ratios. On the other hand, in the theory of companies' activity analysis, return on assets ratio is ratio that shows the value of production divided from the value of the tangible assets (Mackevičius, 2007).

In the financial analysis literature (Bagdžiūnienė, 2005; Buškevičiūtė, Kanapickienė and Patašius, 2010; Juozaitienè, 2007; Liaubienè and Martirosianiené, 2008; Labonaitė and Subačienė, 2014; Mackevičius, Molienė and Poškaitè, 2008; Gibson, 2012; Dunn, 2010; Bernstein, 1993; Савицкая, 2003; Black, 2004; Brigham and Daves, 2004; Maynard, 2013 and others), usually only the calculation formulae of some profitability ratios are presented separately without any attention to evaluation of their values. In most cases, gross and net profitability (i.e. profitability of sales) are analysed. There is a lack of systematic approach when performing complex analysis of companies' activity profitability in the aspect of assets and equity.

The object of the research is the complex analysis of companies' profitability.

The aim of the article is to prepare a methodology of complex analysis of companies' profitability, so the companies' managers could use it to determine profitability of sales, assets and equity, objectively asses their changes and the factors influencing them, and make right management decisions.

The sources of the research are scientific publications by Lithuanian and foreign authors, business accounting standards: $2^{\text {nd }}$ BAS "Balance sheet", $3^{\text {rd }}$ BAS "Statement of profit or loss", $10^{\text {th }}$ BAS "Income", etc.

The research methods are the analyses of scientific literature, collection, comparison, classification and generalization of information.

\section{The significance of profit and profitability analysis in modern competitive market conditions}

Profit is the ratio that defines company's activity the best: it is related to other company's activity ratios, which are assets, equity, liabilities, revenue, expenses, etc. Profit influences these ratios and they influence profit. Profit shows how efficient a company is as well as its positive and negative work sides. International Financial Reporting Standards state that profit and profitability are often used to evaluate companies' activity as well as determine changes of economic resources (Tarptautiniai finansinès atskaitomybès standartai, 2007, p.36).

Every company's goal is to get as high profit as possible, even in 1940, one of the most famous Lithuanian financial scientist V. Jurgutis wrote that if a company does not generate profit in a few years, one has to think that the country does not need such company or it is managed poorly (Jurgutis, 1940, p. 485). Especially now in modern competitive market conditions - companies ought to generate higher profits. If a company is profitable enough, then it can invest, expand its activities, make new production, provide services and thus hold 


\section{ENTREPRENEURSHIP AND SUSTAINABILITY ISSUES}

ISSN 2345-0282 (online) http://jssidoi.org/jesi/ 2016 Volume 4 Number 1 (September)

a stable position in the market (Mackevičius, 2007, p.178). So it is crucial that every company would perform profit analysis and seek how to increase the profit. Yet, it has to be noted that absolute profit ratio does not show appropriate position of company's activity. Suppose that if three companies of the same size and sector generated $€ 0.3$ million profit then we cannon conclude that these companies were equally profitable. Therefore, it is important to compare absolute profit ratio with other ratios of company's activity, especially with sales revenue, assets and equity, i.e. to calculate and evaluate profitability ratios. It is essential to perform profit and profitability analysis regardless of whether the company is profitable or not. It has to be noted that the percentage of profitable companies in Lithuania has grown from $51.4 \%$ to $63 \%$ in the period of $2010-2014$, i.e. by $11.6 \%$ (see table 1 ).

Table 1. Profitable and loss-making Lithuanian companies in 2010-2014 (percent.)

\begin{tabular}{|c|c|c|c|}
\hline Year & Profitable & Loss-making & Difference \\
\hline 2010 & 51.4 & 48.6 & +2.8 \\
\hline 2011 & 58.9 & 41.1 & +17.8 \\
\hline 2012 & 59.8 & 40.2 & +19.6 \\
\hline 2013 & 61.2 & 30.8 & +30.4 \\
\hline 2014 & 63.0 & 37.0 & +26.0 \\
\hline
\end{tabular}

Source: compiled by the author based on Verslo struktūros rodikliai, 2014 [Structural Business Statistic Indicators 2014]. Vilnius: Statistics Lithuania, 2016, p. 36.

Even though that the number of profitable companies has been rising steadily in the past five years, yet their profitability is not high. That is shown by the table 2 data.

Table 2. Profit and profitability ratios of Lithuanian companies in 2010-2014

\begin{tabular}{|l|c|c|c|c|c|c|}
\hline \multicolumn{1}{|c|}{ Ratio } & $\mathbf{2 0 1 0}$ & $\mathbf{2 0 1 1}$ & $\mathbf{2 0 1 2}$ & $\mathbf{2 0 1 3}$ & $\mathbf{2 0 1 4}$ & $\begin{array}{c}\mathbf{2 0 1 4} \text { compared } \\
\text { to 2010 (+, -) }\end{array}$ \\
\hline Sales revenue (millions of EUR) & 50.515 & 60.830 & 66.631 & 70.584 & 72.022 & 21.507 \\
\hline Gross profit (millions of EUR) & 10.181 & 11.447 & 12.353 & 13.030 & 14.158 & +3.977 \\
\hline Net profit (millions of EUR) & 966 & 1.880 & 2.133 & 2.079 & 2.242 & 1.276 \\
\hline Gross profitability (percent.) & 20.2 & 18.8 & 18.5 & 18.5 & 19.7 & $-0,5$ \\
\hline Net profitability (percent.) & 1.95 & 3.1 & 3.2 & 2.9 & 3.1 & +1.2 \\
\hline
\end{tabular}

Source: compiled by the author based on Verslo struktūros rodikliai 2014 [Structural Business Statistic Indicators 2014]. Vilnius: Statistics Lithuania, 2016, p. 27.

From the table 2 it can be seen that the ratios of gross and net profitability has changed insignificantly, yet they are not high enough so the companies would be able to compete in the market efficiently. It especially concerns net profitability ratios.

Of course, profitability ratios of some economy sectors and companies are considerably better. That is shown by the table 3 data.

One can see from the table 3 that the highest gross profitability was in the sector of education (58.1\%), while the lowest one was in manufacturing (14.6\%). Respectively, net profitability was the highest in information and communication and professional, scientific and technical activities sectors and accounted for $33.2 \%$ whereas the lowest net profitability ratio is in the economic activity of repair of computers and personal and household goods, other personal service activities (0.3\%). The highest difference between gross and net profitability $(+50.4 \%)$ is seen in the education economic activity, which shows that operating expenses make up a large portion of all expenses. 
Table 3. Gross and net profitability ratios in particular economic activities in 2014 (percent.)

\begin{tabular}{|c|c|c|c|}
\hline Economic activity & $\begin{array}{c}\text { Gross } \\
\text { profitability }\end{array}$ & $\begin{array}{c}\text { Net } \\
\text { profitability }\end{array}$ & $\begin{array}{c}\text { Difference } \\
(+,-)\end{array}$ \\
\hline Total & 19.7 & 3.1 & +16.6 \\
\hline Forestry and logging, fishing and aquaculture & 36.5 & 2.5 & +34.0 \\
\hline Mining and quarrying & 24.8 & $\mathrm{x}$ & $\mathrm{x}$ \\
\hline Manufacturing & 14.6 & $\mathrm{x}$ & $\mathrm{x}$ \\
\hline Electricity, gas, steam and air conditioning supply & 29.8 & $\mathrm{x}$ & $\mathrm{x}$ \\
\hline Water supply; sewerage, waste management and remediation activities & 22.4 & 5.1 & +17.3 \\
\hline Construction & 20.8 & 3.8 & +17.0 \\
\hline Wholesale and retail trade; repair of motor vehicles and motorcycle & 15.9 & 2.5 & +13.4 \\
\hline Transportation and storage & 19.0 & 3.8 & +15.2 \\
\hline Accommodation and food service activities & 48.1 & $\mathrm{x}$ & $\mathrm{x}$ \\
\hline Information and communication & 42.7 & 33.2 & +9.5 \\
\hline Real estate activities & 45.9 & 15.0 & +30.9 \\
\hline Professional, scientific and technical activities & 48.0 & 33.2 & +14.8 \\
\hline Administrative and support service activities & 30.8 & 8.2 & +22.6 \\
\hline Education & 58.1 & 7.7 & +50.4 \\
\hline Human health and social work activities & 56.1 & 8.1 & +48.0 \\
\hline Arts, entertainment and recreation & 18.9 & 1.9 & +17.0 \\
\hline $\begin{array}{l}\text { Repair of computers and personal and household goods, other personal } \\
\text { service activities }\end{array}$ & 43.8 & 0.3 & +43.5 \\
\hline
\end{tabular}

Source: compiled by the author based on Verslo struktūros rodikliai 2014 [Structural Business Statistic Indicators 2014,]. Vilnius: Statistics Lithuania, 2016, p. 38.

One of the most important sources to increase profitability is constant and detailed analysis of it. It has to be noted that most of the companies do not pay proper attention to profitability ratios analysis and their evaluation. There is also a lack of specific methodologies of establishing profitability ratios in the financial analysis literature. It is especially important to perform the profitability ratios analysis of not one but few ratios, i.e. to apply methodology of complex analysis of profitability.

\section{The recommended scheme of complex analysis of profitability}

Various internal (companies' managers, employees) and external (investors, customers, suppliers, banks, insurance companies, society) information users are interested in profitability ratios in order to achieve certain goals or interests. Managers of companies are interested in profitability of assets ratios the most to manage assets more rationally and to evaluate company's activity more objectively, whereas investors are more interested in profitability of equity because it shows the profitability of their investments. Those taking part in marketing activity are interested in profitability of sales because it shows the profitability of sales process.

It is not enough to calculate certain profitability ratios for companies' managers to make right decisions; for instance, what business activity should they choose, how to manage the company to ensure its competitiveness and continuity of activity, how to develop the business to make a constant long-term profit, etc. That is why it is crucial to continuously and constantly analyse company's profitability ratios and have a particular methodology of profitability ratio analysis. 
A methodology of complex analysis of profitability ratios is proposed which, when implemented in practice, might not only help to correctly calculate and evaluate certain profitability ratios, but also to reveal the reserves of profitability enhancement (see fig. 1).

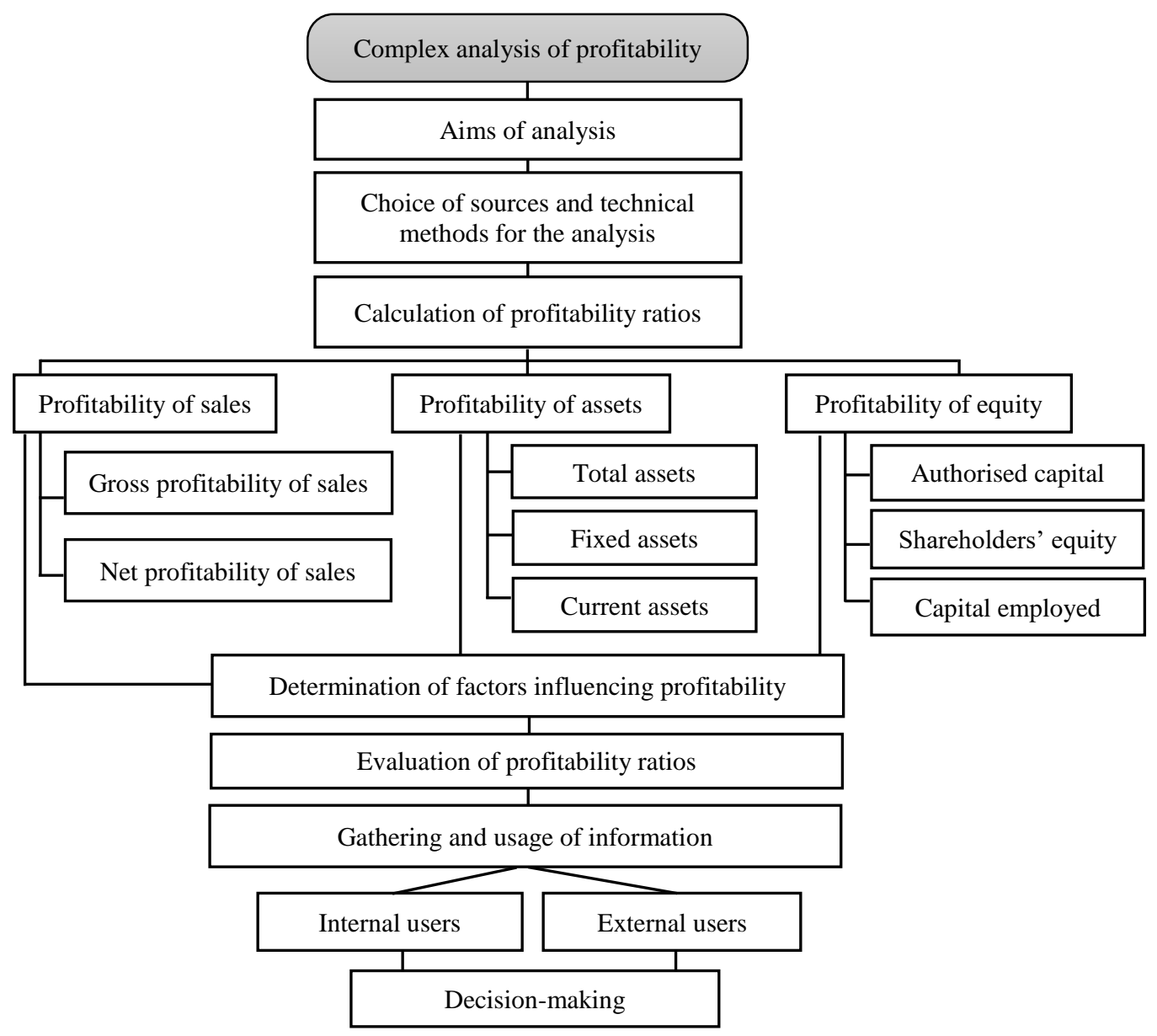

Fig. 1 Methodology of complex analysis of profitability

Source: compiled by the author based on Mackevičius, Molienė and Poškaitė (2008); Mackevičius, Giriūnas and Valkauskas (2014); Ковалев (2002); Савицкая (2005).

\section{The consistency of complex analysis of profitability performance}

As it can be seen from the fig. 1, it is firstly necessary to specify the aims of the profitability analysis, i. e., what one wants to achieve, for instance, to calculate current or next year profitability, determine the factors influencing it, etc. Then specific information sources are selected: budget-standard, financial accounting, financial statements and non-accounting sources. When analysing profitability, it is essential to use the data of balance sheet, profit (losses), cash-flow statements, as well as ledger accounts: 11 "Intangible assets", 12 "Tangible assets", 16 "Financial assets", 17 "Other fixed assets", 20 "Inventories", 24 "Amounts receivable within one year", 26 "Current investments", 27 "Cash and cash equivalents", 30 "Capital", 34 "Retained earnings 


\section{The International Journal \\ ENTREPRENEURSHIP AND SUSTAINABILITY ISSUES}

ISSN 2345-0282 (online) http://jssidoi.org/jesi/ 2016 Volume 4 Number 1 (September)

(losses)", 50 "Sales revenue", 60 "Cost of sales", etc. When choosing methods of complex analysis of profitability, it is appropriate to use comparison, classification, elimination, specification, generalization, heuristic and others.In the complex analysis of profitability, it is essential to decide which profitability ratios are going to be calculated and why. It is suggested to calculate these most important profitability ratios (see table 4).

Table 4. The most important profitability ratios

\begin{tabular}{|c|c|c|}
\hline The titles of the ratios & Calculation of the ratios & Importance of the ratios \\
\hline 1. Gross profitability of sales & $\frac{\text { Gross profit }}{\text { Sales revenue }}$ & $\begin{array}{l}\text { This ratio shows the ability to sell the production above } \\
\text { its cost of sales }\end{array}$ \\
\hline 2. Net profitability of sales & $\frac{\text { Net profit }}{\text { Sales revenue }}$ & $\begin{array}{l}\text { This ratio shows the sales profitability after evaluating all } \\
\text { the income and expenses }\end{array}$ \\
\hline $\begin{array}{l}\text { 3. Net profitability of total } \\
\text { assets }\end{array}$ & $\frac{\text { Net profit }}{\text { Total assets }}$ & $\begin{array}{l}\text { This ratio shows how much euros profit goes to one assets } \\
\text { euro. }\end{array}$ \\
\hline $\begin{array}{l}\text { 4. Net profitability of fixed } \\
\text { assets }\end{array}$ & $\frac{\text { Net prof it }}{\text { Fixed assets }}$ & This ratio shows the usage efficiency of fixed assets \\
\hline $\begin{array}{l}\text { 5. Net profitability of current } \\
\text { assets }\end{array}$ & $\frac{\text { Net profit }}{\text { Current assets }}$ & This ratio shows the usage efficiency of current assets \\
\hline $\begin{array}{l}\text { 6. Net profitability of } \\
\text { authorised capital }\end{array}$ & $\frac{\text { Net profit }}{\text { Authorised capital }}$ & $\begin{array}{l}\text { This ratio shows how much of net profit the company } \\
\text { received for every euro invested by the shareholders }\end{array}$ \\
\hline $\begin{array}{l}\text { 7. Net profitability of } \\
\text { shareholders' equity }\end{array}$ & $\frac{\text { Net profit }}{\text { Shareholders'equity }}$ & $\begin{array}{l}\text { This ratio shows profit created by shareholders' equity } \\
\text { and managers' work efficiency by using invested capital }\end{array}$ \\
\hline $\begin{array}{l}\text { 8. Net profitability of capital } \\
\text { employed }\end{array}$ & $\begin{array}{l}\text { Net profit+ Interest } \\
\text { Shareholders'equityt } \\
\text { Long - term liabilities }\end{array}$ & $\begin{array}{l}\text { This ratio shows company's functioning possibilities and } \\
\text { the level of development }\end{array}$ \\
\hline
\end{tabular}

Source: compiled by the author, based on Mackevičius, 2007.

Various internal and external users seeking certain goals might also calculate other profitability ratios. By analysing profitability of sales, it is also possible to calculate sales profitability of typical activities, sales profitability of financial and investment activities, sales profitability of ordinary activities, etc. And by analysing profitability of assets it is possible to calculate not only the profitability of total assets, fixed assets and current assets but also the profitability of the most important fixed and current assets elements, for instance, the profitability of equipment and machinery, profitability of vehicles, profitability of inventories and others.

After calculating various profitability ratios, it is crucial to properly evaluate their values. A lot of authors draw attention to this (Fridson and Alvarez, 2011; Mackevičius, Giriūnas and Valkauskas, 2014; Maynard, 2013; Plenborg, and Petersen, 2011; Juozaitienè, 2007, Sinha, 2009; Савицкая, 2003, 2005 and others). Naturally, a question arises: what should be the level of sales, assets and equity profitability for a company to be competitive and beneficial to the society. The Lithuanian Statistical Society, Department of Statistics Lithuania and SOE "Statistikos tyrimai" [Statistics studies] prepared a financial ratios evaluation methodology with profitability ratios values as intended guidelines (see table 5).

Table 5. Guidelines of evaluating a company's profitability ratios values

\begin{tabular}{|l|l|c|c|c|c|c|}
\hline \multirow{2}{*}{ No. } & \multicolumn{3}{|c|}{ The titles of the ratios } & \multicolumn{3}{c|}{ Values } \\
\cline { 3 - 7 } & & Very good & Good & Satisfactory & $\begin{array}{c}\text { Non- } \\
\text { satisfactory }\end{array}$ & Bad \\
\hline 1. & Gross profitability of sales, percentage & $>35$ & $>15$ & $<15$ & $<7$ & Negative \\
\hline 2. & Net profitability of sales, percentage & $>25$ & $>10$ & $<10$ & $<5$ & Negative \\
\hline 3. & Net profitability of total assets, percentage & $>20$ & $>15$ & $>8$ & $<8$ & Negative \\
\hline 4. & Net profitability of shareholders' equity, percentage & $>30$ & $>20$ & $>10$ & $<10$ & Negative \\
\hline
\end{tabular}

Source: compiled by the author, based on İmonès finansinès būklès vertinimo rodikliai 2000-2003 [Indicators measuring companies' financial standing 2000 - 2003]. Vilnius: Statistics Lithuania, 2004, p.17. 


\section{The International Journal \\ ENTREPRENEURSHIP AND SUSTAINABILITY ISSUES}

ISSN 2345-0282 (online) http://jssidoi.org/jesi/

2016 Volume 4 Number 1 (September)

After comparing profitability values recommended in table 5 with factual profitability values in table 3 , it is seen that gross profitability in some Lithuanian economic activities, such as forestry and logging, fishing and aquaculture; accommodation and food service activities; information and communication; real estate activities; education; human health and social work activities and others is evaluated as very good. However, the net profitability ratios in the major part of economic activities (forestry and logging, fishing and aquaculture; construction; wholesale and retail trade; repair of motor vehicles and motorcycle; transportation and storage; arts, entertainment and recreation; repair of computers and personal and household goods, other personal service activities) are evaluated as non-satisfactory. It shows that companies are able to optimize the cost of sales, yet are facing problems when managing operating expenses.

Naturally, the values given in table 5 should only be treated as guidelines. Profitability ratios of companies from different economic sectors may differ considerably because of activity characteristics typical to them. Thus the most proper option would be for the companies themselves to review their profitability ratios of the previous few years, establish their own guidelines for profitability ratios and follow them.

Because of very complex, constantly changing and competitive circumstances of modern market, it is appropriate to prepare a four-level scheme to evaluate profitability ratios, which looks like this:

1. Excellent: it is the value that considerably (more than $100 \%$ ) exceeds the medium level of the industry sectors' companies' ratio.

2. Good: when the company's ratio exceeds (less than 100\%) the medium level of the industry sectors' companies' ratio.

3. Satisfactory: when the company's ratio matches the medium level of the industry sectors' companies' ratio or slightly diverges from it.

4. Bad: when the company's ratio is lower than the medium level of the industry sectors' companies' ratio.

The guidelines for profitability ratios values - taking into account the dynamism of modern business and constantly growing competition - might be established for a certain period, for instance 3-5 years, and changed afterwards.

When performing the complex analysis of profitability, it is important to calculate factors influencing a certain level of profitability. The factors are calculated separately for profitability of sales, assets and equity. Four main factors have an impact on gross profitability of sales: 1) the production sales volume; 2) the structure and range of production sales; 3) cost of sales; 4) price. As the products and services sales volume increases, yet the other factors stay the same, the gross profit - and meanwhile profitability - also increases. The impact of structure and range is calculated by comparing basic gross profitability of sales calculated according to the factual production volume with a base ratio. The cost of sales influence is determined by comparing the factual and basic gross profitability of sales recalculated for factual sales volume. The price factor is estimated by comparing factual gross profitability of sales - which is calculated by dividing the calculated current gross profit from factual sum of sales revenue - with factual gross profitability recalculated for base prices. It is appropriate to calculate the factors influencing profitability of assets and equity using the DuPont pyramid or its formulae:

1) Net profitability of assets $=\frac{\text { Net profit }}{\text { Total assets }}=\frac{\text { Net profit }}{\text { Salesrevenue }} \times \frac{\text { Salesrevenue }}{\text { Total assets }}=$ Net profitability of sales $\times$ $\times$ Total assets turnover;

2) Net profitability of shareholders' equity $=\frac{\text { Net profit }}{\text { Shareholders' equity }}=\frac{\text { Net profit }}{\text { Salesrevenue }} \times \frac{\text { Salesrevenue }}{\text { Total assets }} \times$ $\times \frac{\text { Total assets }}{\text { Sharehoders' equity }}=$ Net profitability of sales $\times$ Total assets turnover $\times$ Equity multiplier. 
Therefore net profitability of sales and total assets turnover have influence on net profitability of assets, whereas apart from these factors, equity multiplier influences net profitability of shareholders' equity. This is the factors of first level. In order to determine the influence of first, second and third level factors, the DuPont pyramid analysis is performed. We provide an example of profitability of shareholders' equity pyramid analysis by using information on Lithuanian financial accounting and reporting (see fig.2).

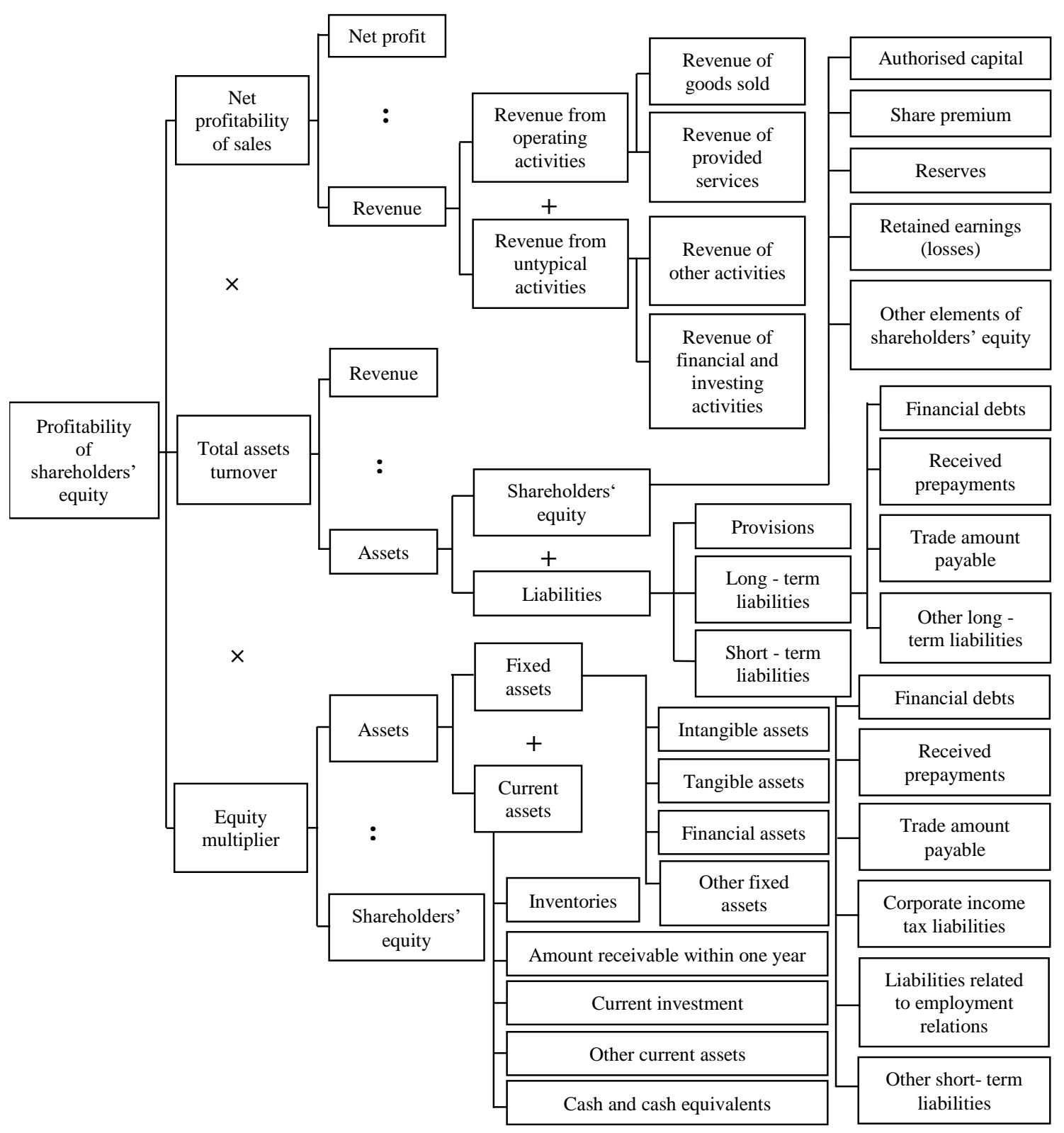

Fig. 2. Du Pont pyramid analysis of profitability of shareholders' equity

Source: compiled by the author in accordance with valid Lithuanian financial accounting and reporting information 


\section{The International Journal
STAINABILITY ISSUES}

ISSN 2345-0282 (online) http://jssidoi.org/jesi/

2016 Volume 4 Number 1 (September)

Apart from these factors, whose influence is easily calculated, profitability of companies is also influenced by various internal and external factors, which could be calculated only approximately or could even be impossible to calculate them, yet their influence cannot be denied (Šimberová et al. 2015). These factors are also attributed to the most important factors influencing company's profitability: 1) economic (overall level of economic development, the monetary, fiscal and tax policy of the state, inflation, etc.), 2) political and legal (legislation inciting business establishment and development, the state's foreign economic policies, aid for small businesses, and others), 3) social and cultural (the level of unemployment, population and geographical distribution, basic and economics education of the population and others), 4) technological (state-level incitement of efficient usage of technologies and innovations, state-level promotion of knowledge-based society, occupational safety, and others), 5) ecological (pollution of air, water, earth and its resources, noise, excessive heat or cold, and others).

Internal factors have even more significant influence, these are most notable: managers' activity (actions of managers are of particular importance when establishing the company's activity policies and strategy, Mentel et al. 2016), personnel management policy; i.e. anticipation of personnel strategy, selection of employees, employees training and education, employees' wages, employees relationships management (Matetskaya 2015; Prause, Hunke 2014), organisational and management structure (Fuschi, Tvaronavičienè 2016) of a company, and others.

Well-executed complex analysis of profitability gathers a lot of information about profitability of sales, assets and equity whose information is especially valuable for internal and external users of information making certain decisions. The information of analysis might help the companies' managers not only to forecast company's profitability but also to precisely evaluate possible risks and potential possibilities, establish economic, technical and other conditions of current and future business, the level and characteristics of competition, the possibilities and strategies of competitors, etc. It can even be stated that complex analysis of profitability helps to efficiently manage company's resources, make right investment and financial decisions and eventually ensure good solvency and profitable activity.

\section{Conclusions}

Various internal and external users as well as most of the authors usually calculate and analyse gross or net profitability ratios. However, these ratios ought to be named as gross and net profitability of sales because they are calculated by respectively dividing gross or net profit from sales revenue. In modern market conditions which are competitive and dynamic, it is essential to calculate and analyse not only the profitability of sales ratio but also the profitability of assets and equity ratios.

The complex sales, assets and equity profitability analysis methodology has not yet been established. The complex analysis methodology recommended in the article comprises: 1) determination of analysis aims; 2) choice of analysis sources and technical methods; 3) calculation and evaluation profitability of sales (gross and net), profitability of assets (total assets, fixed and current assets), profitability of equity (authorized capital, shareholders' equity and capital employed); 4) determination of factors influencing profitability; 5) usage of information collected during the analysis for internal and external users purposes.

The recommended methodology of complex analysis of profitability can be successfully applied to companies of various size and activity. After successfully applying it, it is possible to objectively assess efficiency of company's activity, potential risks, competitiveness and possibilities of continuity. 


\section{ENTREPRENEURSHIP AND SUSTAI \\ The International Journal}

ISSN 2345-0282 (online) http://jssidoi.org/jesi/ 2016 Volume 4 Number 1 (September)

\section{References}

10 $0^{\text {th }}$ Business Accounting Standard "Income". 2015. The Authority of Audit and Accounting. Available on the Internet: <http://www.aat.lt/index.php?id=14>.

$2^{\text {nd }}$ Business Accounting Standard "Balance sheet". 2015. The Authority of Audit and Accounting. Available on the Internet: <http://www.aat.lt/index.php?id=14 >.

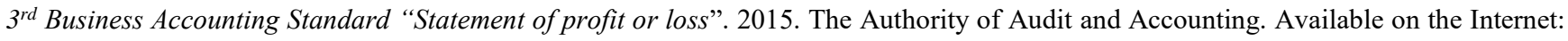
<http://www.aat.lt/index.php?id=14>.

Bagdžiūnienė, V. 2005. Finansiniu ataskaitu analizè. Esmè ir verslo situacijos [Analysis of financial statements. The essence and situations of business]. Vilnius: Conto litera.

Bernstein, L.A. 1993. Financial Statement Analysis. Theory, Application and Interpretation. $5^{\text {th }}$ ed. New York: Irwin.

Black. G. 2004. Applied Financial Accounting and Reporting. Oxford: Oxford University Press.

Brigham, E.F., Daves, P.R. 2004. Intermediate Financial Management. $8^{\text {th }}$ ed. Thomson, South-Western.

Buškevičiūtè, E., Kanapickienė, R., Patašius, M. 2010. Finansiniu rezultatu analize [Analysis of financial results]. Kaunas: Technologija.

Dunn, J. 2010. Financial Reporting and Analysis. Chichester: John Wiley \& Sons Ltd.

Fridson, M.S., Alvarez, F. 2011. Financial Statement Analysis. A Practitioner's Guide. $4^{\text {th }}$ ed. New Jersey: John Wiley and Sons, Inc.

Fuschi, D. L.; Tvaronavičienė, M. 2016. A network based business partnership model for SMEs management, Entrepreneurship and Sustainability Issues 3(3): 282-289. http://dx.doi.org/10.9770/jesi.2016.3.3(5)

Gibson, Ch. H. 1992. Financial Statement Analysis: Using Accounting Information. $5^{\text {th }}$ ed. Cincinnati, OH: South-Western Publishing Co.

Gibson, Ch. 2012. Financial Reporting and Analysis. Using Financial Accounting Information. 13 ${ }^{\text {th }}$ ed. Mason, OH: South-Western Cengage Learning.

Imoniu finansinès büklès vertinimo rodikliai 2000 - 2003 [Indicators measuring companies' financial standing 2000 - 2003 ]. 2004. Vilnius: Statistics Lithuania.

Juozaitienè, L. 2007. Imonès finansai: analizè ir valdymas [Company's finance: analysis and management]. Šiauliai: The publisher of Šiauliai University.

Jurgutis, V. 1940. Bankai. [Banks]. Kaunas: Šviesa.

Labonaitè, G., Subačienè, R., 2014. Grynojo pelningumo vertinimo metodika [Methodology for net profitability analysis]. Buhalterinès apskaitos teorija ir praktika [Accounting Theory and Practise], 16: 78-87.

Liaubienè, R., Martirosianienè, L. 2008. Pelningumo rodikliu analizès problemos [Problems of analysis of profitability ratios], Science and studies of accounting and finance: problems and perspectives: proceedings of $6^{\text {th }}$ international scientific conference. Lithuanian University of Agriculture, Kaunas, p. $102-106$.

Mackevičius, J. 2007. Imoniu veiklos analizė [Analysis of enterprises activity]. Vilnius: TEV.

Mackevičius, J., Giriūnas, L., Valkauskas, R. 2014. Finansine analizė [Financial analysis]. Vilnius: Vilniaus universiteto leidykla.

Mackevičius, J., Molienė, O., Poškaitė, D. 2008. Bendrojo pardavimo pelningumo kompleksinès analizès metodika [Methodology of complex analysis of return on sales], Ekonomika [Economics], 81: 74-90.

Matetskaya, M. 2015. Education programmes for entrepreneurs in the creative industries in St. Petersburg, Entrepreneurship and Sustainability Issues 3(1): 66-73. http://dx.doi.org/10.9770/jesi.2015.3.1(6)

Maynard, J. 2013. Financial Accounting, Reporting and Analysis. Oxford: Oxford University Press. 


\section{ENTREPRENEURSHIP AND SUSTA \\ The International Journal}

ISSN 2345-0282 (online) http://jssidoi.org/jesi/ 2016 Volume 4 Number 1 (September)

Mentel, G.; Szetela, B.; Tvaronavičienè, M. 2016. Qualifications of managers vs. effectiveness of investment funds in Poland, Economics \& Sociology 9(2): 126-137.

Plenborg, T., Petersen, Ch. 2011. Financial Statement Analysis. Valuation - Credit Analysis - Executive Compensation. Essex: Pearson Education.

Poškaitè, D. 1994. Finansinès büklès analizè rinkos sąlygomis [Analysis of financial standing under market conditions]. Vilnius: Vilniaus universiteto leidykla.

Prause, G.; Hunke, K. 2014. Secure and sustainable supply chain management: integrated ICT-systems for green transport corridors, Journal of Security and Sustainability Issues 3(4): 5-16. http://dx.doi.org/10.9770/jssi.2014.3.4(1)

Šimberová, I.; Chvátalová, Z.; Kocmanová, A.; Hornungová, J.; Pavláková Dočekalová, M. 2015. Sustainable value in measuring of corporate sustainability: approaches and their evaluation, Journal of Security and Sustainability Issues 4(3): 241259. http://dx.doi.org/10.9770/jssi.2015.4.3(5)

Sinha, G. 2009. Financial Statement Analysis. New Delhi: PHI Ltd.

Standard chart of ledger account. 2016. The Authority of Audit and Accounting. Available on the Internet: <http://www.aat.lt/index.php?id=14>.

Stickney, C. P. 1993. Financial Statement Analysis. A Strategic Perspective. $2^{\text {nd }}$ ed. The Dryden Press.

Stickney, C.P.; Brown, P.; Wahlen, J.M. 2006. Financial Reporting, Financial Statement Analysis, and Valuation. A Strategic Perspective. $6^{\text {th }}$ ed. Mason: South-Western College Publishing.

Tarptautiniai finansinès atskaitomybès standartai [International Financial Reporting Standards]. (2007). Vilnius: Apskaitos institutas.

Tvaronavičienè, M.; Černevičiūtė, J. 2015. Technology transfer phenomenon and its impact on sustainable development, Journal of Security and Sustainability Issues 5(1): 87-97. DOI: http://dx.doi.org/10.9770/jssi.2015.5.1(7)

Verslo struktūros rodikliai 2014 [Structural Business Statistic Indicators 2014]. 2016. Vilnius: Statistics Lithuania.

White, G.Y., Sondhi, A.C., Fried, D. 1994. The Analysis and the Use of Financial Statements. New York: John Wiley \& Sons.

Ковалев, В.В. 2002. Финансовый анализ: методы и процедуры [Financial analysis: methods and procedures]. Москва: Финансы и статистика.

Савицкая, Т.В. 2003. Економический анализ [Economic analysis]. 8-ое изд. Москва: Новое знание.

Савицкая, Т.В. 2005. Методика комлексного анализа хозяйственной деятельности [Methodology of economic activity complex analysis]. Москва: ИНФРА.

Daiva TAMULEVIČIENÉ is the Assistant of Accounting and Auditing Department, PhD student. Scientific interests: controlling, management accounting, modern cost accounting systems, financial management, financial analysis. Vilnius University, Faculty of Economics, department of Accounting and Audit.

Copyright (C) 2016 by author(s) and VsI Entrepreneurship and Sustainability Center This work is licensed under the Creative Commons Attribution International License (CC BY).

http://creativecommons.org/licenses/by/4.0/

(c) (i) Open Access 